This item was submitted to Loughborough's Research Repository by the author.

Items in Figshare are protected by copyright, with all rights reserved, unless otherwise indicated.

\title{
Ultranationalism, democracy and the law: insights from Côte d'Ivoire
}

PLEASE CITE THE PUBLISHED VERSION

https://doi.org/10.1017/S0022278X13000827

PUBLISHER

(c) Cambridge University Press

VERSION

AM (Accepted Manuscript)

LICENCE

CC BY-NC-ND 4.0

REPOSITORY RECORD

Piccolino, Giulia. 2019. "Ultranationalism, Democracy and the Law: Insights from Côte D'ivoire”. figshare. https://hdl.handle.net/2134/25068. 


\title{
Ultranationalism, democracy and the law: insights from Côte d'Ivoire
}

\section{GIULIA PICCOLINO}

Post-doctoral Research Fellow, Centre for the Study of Governance Innovation, Department of Political Sciences, University of Pretoria, Lynwood road, 0002, Pretoria, South Africa

giulia.piccolino@yahoo.it

Submitted Manuscript Under Review. The definitive version of this article will appear on The Journal of Modern African Studies, 52(1), 2014 (Cambridge University Press (C). http://journals.cambridge.org/action/displayJournal?jid=MOA

\begin{abstract}
Although much has been written about the ideology of Laurent Gbagbo's Front Populaire Ivoirien in Côte d'Ivoire and its impact on the Ivorian politico-military crisis, little attention has been paid to the ubiquitous role of the law in the discourse and political strategy of the pro-Gbagbo elite. The Ivorian case may provide important insights about the connection between ultranationalist ideology and a legalist, formalist conception of democracy and national sovereignty. The article analyzes the circumstances of the emergence of 'legalist nationalism' in Côte d'Ivoire by looking at key episodes of the Ivorian transition between 2002 and 2012. The article discusses the relevance of Pierre Englebert's concept of 'legal command' and the turbulences of democratic transitions in accounting for the prominence of legalism in Ivorian politics. It explores the implications of the Ivorian case for understanding the connection between law and politics in Africa.
\end{abstract}

\section{INTRODUCTION}

On 4 December 2010, Laurent Gbagbo, the outgoing president of Côte d'Ivoire, took a new presidential oath at the Presidential Palace in Abidjan. The ceremony was notable for the almost total absence of the diplomatic corps. As a matter of fact, the ceremony was 
deemed a provocation by most of the members of the so-called international community. For them, the outcome of the presidential elections was not in question: the winner of the second round, held on November 28, was Gbagbo's rival, former Prime Minister Alassane Dramane Ouattara, who had obtained $54.10 \%$ of the votes, as announced by Youssouf Bakayoko, the head of the Independent Electoral Commission (IEC). The United Nations (UN) Special Representative of the Secretary General (SRSG) in Côte d'Ivoire Young Jin Choi, had endorsed the IEC results as part of his mandate of certification of the elections. In the eyes of Gbagbo's supporters, however, the IEC announcement was flawed and the only valid results were those expressed by the Constitutional Council, which had invalidated the election in seven Northern circumscriptions and proclaimed Gbagbo the winner. $^{1}$

By staging his investiture, Gbagbo was thus openly challenging international public opinion, as well as a part of national public opinion. His stubborn and provocative stance was perhaps not unexpected from a man who had begun his political career as a staunch opponent of the then apparently untouchable regime of Félix Houphouët-Boigny. Moreover, Gbagbo's antagonistic stance towards the international community, particularly France and the UN, had several precedents since the conclusion of the 2003 LinasMarcoussis agreement (Piccolino 2012), which had brought a shaky end to violent conflict between his regime and the FN. In public discourses, the Gbagbo regime claimed to break away from the shackles of 'special relationship' with France and the Western block, which had been a building block of previous regimes (Akindès 2004; Bouquet 2011; McGovern 2011).

One could thus have expected Gbagbo to stress the problem of national sovereignty in his speech at the oath ceremony, or to present himself as a champion of anticolonialism and African dignity, as he had done on other occasions. Instead, the self-styled president chose to open his speech with another theme: 
Today, I understand better why there are so many crises in Africa... What I would like to stress today is that these crises come out also from the fact that people are outlaw. People do not like to respect the law and the procedures that stem from it. There is no strong State, no strong Republic without laws and procedures... The only strong Republic is the one that stands on the rules of the law. Since I have become president, I have realized that all the crises that we have known have come out from the non respect of the law, of the jurisdiction and of the procedures [la loi, le droit et les procédures] that this law produces. However, we cannot claim that we are building democracy and put aside the law and the procedures stemming from it (Fraternité Matin 6.09.2010, italicised by the author of this article).

The words 'loi' ('law'), 'droit' ('right', but also synonymous of law in French), 'procédures' (procedures) recur in an almost obsessive fashion in this speech, especially in connection with democracy. And, in a subsequent speech where he expressed his views on the post-election crisis, Gbagbo continued to insist that 'all the troubles that we are witnessing today in Côte d'Ivoire have come out from the refusal of my rival to abide by the laws, the rules and the procedures applicable in our country' (Gbagbo 2010).

One may perhaps wonder why a man who had in the past challenged the existing order as a political opponent should devote so much space to the argument of the law and of the legal order. Researchers have labelled the Gbagbo regime's ideology as 'ultranationalist', 'anticolonialist', 'nativist', 'ethnonationalist', 'populist' (Arnaut 2008; Banégas 2006; Cutolo 2010; Marshall-Fratani 2006), but despite an abundant literature dedicated to Ivorian nationalism, the legalistic dimension of this nationalism has received little attention. Moreover, the problematic and ambiguous role of the law in Côte d'Ivoire's recent history has been downplayed by the international and human rights organizations' insistence over the necessity to restore the 'rule of law' (Hellweg 2013; Bovcon 2013). Francis Akindès, however, has nevertheless noticed that, during the political transition that 
followed the 2002 short-lived civil conflict, a legalistic interpretation of democracy occupied a central place in the public discourse of Gbagbo's party Front Populaire Ivoirien (FPI) and of the former president's supporters (Akindès, 2010).

This article discusses possible links between ultranationalism and a legalist, formalist conception of democracy and national sovereignty, looking at the Ivorian case and Africa more broadly. My argument is that the concept of 'legal command' and its role in African politics, as theorized in the work of Pierre Englebert, provide a useful framework to understand the centrality of the law in the Gbagbo's regime political discourse. However, for understanding the emergence of Gbagbo's legalist ultranationalism one has also to integrate factors that are specifically Ivorian in the explanation. Moreover, the role of legalism in African politics should also be understood in the context of resistance of African political elites to democratization.

The article is structured as following. I begin by discussing the nature of the state and politics in Africa and the centrality of legal command in African politics. In the second paragraph, I reconnect the concept of legal command with the Ivorian experience, discussing the factors that have led to the emergence of ultranationalist legalism in Côte d'Ivoire. I look in particular at Côte d'Ivoire's turbulent transition to multi-party rule in the ' 90 s and at the outbreak of the 2002 civil war. In the third paragraph I analyze the centrality of legal formalism in the discourse and political strategy of the pro-Gbagbo camp since the conclusion of the Linas-Marcoussis peace agreement to the 2010-2011 postelection crisis. In the conclusion, I discuss the lessons offered by the Ivorian case for understanding the relation between law and politics in Africa.

\section{THE AFRICAN STATE: A JURIDICAL CREATURE?}

The law and the supreme law - the Constitution - are one of the prime formal institutions of a modern state. 'Neo-patrimonial theory' - the dominant, although contested paradigm 
to the study of African politics - posits that the African states are characterized by coexistence of formal institutions and formal rules on the one hand, and informal behaviour on the other. ${ }^{2}$ This interaction provides rent opportunities for political elites and thus access to the state is highly sought and prized.

In practice, however, scholars of African politics have paid more attention to informal institutions as such than to their interaction with formal ones. Concepts such as 'personal rule' (Jackson \& Rosberg 1982a), 'Big Man rule' (Posner \& Young 2007), ‘economy of affection' (Hyden 2005) or 'instrumentalisation of disorder' (Chabal and Daloz 1999) have dominated the debate over African politics. The view that the State in Africa is a mere façade and that 'legitimacy is firmly embedded in the patrimonial practices of patrons' (Chabal \& Daloz, 1999: 16) or in a 'cultural matrix' revolving around metaphors of family and food (Schatzberg 1993) makes difficult to understand how the law and the Constitution may occupy a central place in the discourse of African political elites.

The neglect of the influence of the law seems also motivated by the acknowledgement that it does not play in Africa the role of limitation of the arbitrary character of power that is inscribed in Western conceptions of democracy. The practitioners of international institutions and NGOs routinely deplore the weak development of the rule of law in Africa and in other parts of the developing world and develop projects aimed at strengthening it. The UN, for example, have a dedicated inter-agency working group on rule of law and most current and recent UN peace operations in Africa have included a 'rule of law' section. ${ }^{3}$ On another level, however, the acknowledgement that African reality is dominated by informalization prompts another question: why do formal and legally defined institutions, particularly the state, persist in spite of their apparent inefficacy?

More than twenty years ago, Robert Jackson and Carl Rosberg (Jackson 1990; Jackson \& Rosberg 1982b) tried to respond to this question by drawing attention to the 'juridical' character of Africa's states and of their sovereignty. According to Jackson, most 
African states issued from decolonization were not endowed with full 'empirical sovereignty' at independence, i.e. the capacity to hold the monopoly of force over territory. Nevertheless, the international system had conferred to these states a 'juridical sovereignty' that allowed them to persist in spite of their evident shortcomings.

Jackson's arguments have been considerably nuanced by other scholars (Clapham 1998; Herbst 2000; Krasner 1999). Notably, Jeffrey Herbst has argued that it is more appropriate to trace the origins of 'juridical sovereignty' to the colonial period. Christopher Clapham has observed that Jackson paints a binary opposition between 'empirical' and 'juridical' states, while the matter is more one of 'degrees of statehood'. Stephen Krasner has noticed that absolute sovereignty has always been to some extent 'organized hypocrisy' even in the Western world. Moreover, with the redefinition of state sovereignty that has taken place after the fall of the Berlin Wall, the protection that the international society grants to the 'juridically sovereign' states has ceased to be absolute and unconditional as Jackson paints it. Jackson's observations remain however valuable in one respect: the 'juridically sovereign' nature of the African states has important implications on the way these states conduct their international relations and on their internal mode of governance.

Pierre Englebert (Englebert 2009) is one of the rare authors who has explored the internal implications of the juridical sovereign nature of the African states. Englebert remarks that the increasingly qualified protection of international society does not explain the relative scarcity of internal challenges to the formal existence of the state in Africa. Englebert is particularly concerned by the fact that, even in situations that could be qualified of state failure or de facto secession, political actors continue to define their actions with respect to the 'failed' or divided state and the population expresses strong feelings of belonging and identification with the state.

According to Englebert, the legal nature of the African state and its juridical sovereignty may help unfold the paradox of the vitality of the state. For him, juridical 
sovereignty confers legal command to the African states. This is defined as 'the capacity to control, dominate, extract or dictate through the law' (Englebert 2009: 62). Englebert observes that even if the state is no longer capable to perform its public functions it still retains this residual command, which stems from the fact that the state is the law. He sees in the juridical nature of state power, acquired from international sovereignty, a key for explaining a puzzling phenomenon acknowledged by anthropologists such as Jean and John Comaroff (Comaroff \& Comaroff 2007): the relevance of a 'fetishism of the law' in the midst of political disorder in Africa and in other countries of the 'global South'.

Englebert's concept of legal command finds an expression in many instances, such as the production of official certifications and identity documents, the printing of currency, the right to seize public resources. The definition of the access to citizenship is perhaps the more powerful dimension of this authority, as citizenship grants access to the other benefits that legal command may provide.

'Legal command' is crucial to understand the functioning of neo-patrimonial systems. It offers opportunities for rent seeking not only to the main power holders, but also to the many local authorities, state agents and intermediary actors that are dominated and dominant at the same time. The fact that these authorities embody the legitimacy of the state, defined in legal terms, becomes crucial to their capacity to extract rents even in the absence of administrative effectiveness and coercive capacities. The centrality of 'legal command' implies thus an essentially instrumental view of the law, which becomes a tool to exercise power over others, often in the pursuit of private gain, rather than an instrument for limiting the state's arbitrary power. The 'rule of law' is overcome by the 'rule by law'.

Englebert argues that there is a link between juridical sovereignty and legal command on the one hand and the emergence in Africa of a particular type of nationalism. This nationalism is deprived of the liberating qualities attributed to the assertion of national identity by much early literature on Africa's nationalism (Young 1986). First, this 
nationalism is diversionary and is agitated by the elites in power for neutralizing internal and international threats to their domination. Its aim is to imprint the state's external sovereignty into the hearts and minds of African citizens, in order to make the juridical state appear natural and divert the blame for development failure (Englebert 2009: 198199). Thus, elite-driven nationalism in Africa tends to be self serving and instrumental, rather than to lay the ground for a political project of emancipation and development.

Englebert observes, however, that nationalism is also produced at the grassroots level. In fact, what gives to legal command its resilience and its force is the fact that its benefits are diffused within the society. However, 'this type of nationalism arises from competitive contact with others from the same country, it is solitary and mutually alienating, rather than the expression of the bonds of the community' (Englebert 2009: 204).

Although this article will focus mainly on the diversionary use of nationalism at the elite level, the concept of 'solitary nationalism' seems particularly appropriate to make a sense of some troubling characters of the Ivorian pro-Gbagbo movement of the 'young patriots' (Arnaut 2008; Banégas 2006; Cutolo \& Banégas 2012; Koné 2011). Research carried among the patriots has frequently highlighted the extreme factionalism that characterized the movement (Cutolo \& Banégas 2012; Koné 2011), which is all the more impressive given the absence of substantial ideological differences among groups and factions. These factional struggles make sense only by looking at the competition among patriots for the benefits distributed by the Gbagbo regime and for the monopoly of the 'patriotic' label, which granted access to additional material and moral goods: thus, for the appropriation of power and resources that stems from the legitimacy that only association with the state may confer. 
Pierre Englebert's theory provides a framework for understanding the connection between legal command and ultra-nationalism. Arguably, however, the importance of legal command in politics has not been always constant in Africa and has not everywhere led to the emergence of an ultranationalist ideology imbued of legalism such as in Côte d'Ivoire under the Gbagbo presidency. How can we thus explain Côte d'Ivoire's specificity? To some extent, Englebert's theory is able to account for the emergence of legalism in Côte d'Ivoire and not elsewhere. However, there are also additional elements that contribute to account for the Ivorian case, in particular the relation between legalism and (flawed) democratisation.

It can be argued, following Englebert's framework, that the linkage between nationalism and legalism is more likely to emerge when nationalists have very little but 'the juridical state' to cling upon. 'Illegitimate post-colonial statehood' (Englebert 2000: 12) is an African phenomenon, but not all African states suffer to the same extent of such a 'legitimacy deficit'. Some African countries share a sense of common cultural identity or a history of decolonization struggle that provide a more credible narrative to would be nationalists. In spite of Gbagbo and the young patriots' efforts to wrap their political struggle into a rhetoric of 'second independence' (Banégas 2006), Côte d'Ivoire lacks both. During its first decades of existence, the nation very much identified with its leader, who shaped it in its image. The experience of the Gagnoa revolt, which is often seen as one of the founding moments of Gbagbo's nationalism (Marshall 2006), is a localized and ethnically bounded one that cannot provide the basis for a nation-wide nationalist ideological project.

For understanding the rise of an ultranationalist legalist discourse in Côte d'Ivoire one has also to consider the context of economic recession and state decay that the country experienced since the end of the Houphouët-Boigny 's regime. Englebert observes that a radicalization of nationalism, leading to the emergence of forms of 'nativist nationalism' 
(Bøås 2009; Dorman, Hammet, Nugent 2007) is more likely to emerge in a situation of shrinking state patronage, where some groups try to bar to other groups the access to citizenship and to the legal command that stems from it. He also argues that the importance of 'legal command' is connected to the crisis of the state in its capacity to control effectively the national territory and implement its policies. The more a state is able to exercise effective control, the less it is obliged to insist on its legality. Ultranationalist legalism in Côte d'Ivoire has emerged in a context where the Ivorian administrative apparatus, which was known for its relative efficiency under Houphouët-Boigny, had experienced a decline due to the detrimental identity politics of the '90s. In particular, the loss of control of more than $50 \%$ of the official state territory following the 2002 rebellion has provided the main background for the emergence of ultranationalist legalism.

The role of the Constitution and the law in Côte d'Ivoire should be also interpreted within a longer historical context. When Côte d'Ivoire adopted its first Constitution as an independent state in 1960 there was already an understanding that the typical Western notion of a Constitution as a tool for limiting the power of the ruler had little relevance (Alexander 1963). The Constitution sanctioned the prominence of the president and the executive and left little powers to the legislative branch. Moreover, the Constitution was very little 'popularly owned', both in the sense that its main source of inspiration was exogenous and was provided by the French Constitutional tradition and that it had been drafted with little popular involvement by a small political élite composed by those who were called at the time évolués. The provisions of the Constitution on free and fair election and the right to form political parties remained de facto unapplied for most of the Houphouët-Boigny era. Nevertheless, A.S. Alexander, an American lawyer that worked as an assistant to the President of the Ivorian Supreme Court in 1961-62, contends that Houphouët-Boigny took the Constitution seriously, in so far as it recognized to it an important legitimizing role and saw it as an instrument to consolidate his power. The 
Ivorian Constitution was not a brake on government action but could work as an accelerator (Alexander 1963).

Although these remarks suggest that Houphouët-Boigny was already aware of the importance of legal command, it shall also be remarked that he never relied primarily or exclusively on the appeal of legalism for legitimizing his rule. His political ability in defusing any threat to his rule, the economic successes of his regime and his capacity to readapt Akan traditional notions of legitimate rule (Maddox Toungara 1990) were equally keys. Moreover, Houphouët-Boigny 's system of personal rule was very much condoned at the internal and international level, at a time were authoritarianism and one party rule were seen as necessary elements in a process of nation building. Thus, Houphouët-Boigny 's legitimacy was not continuously questioned due to the democratic deficit of his regime, nor was he obliged to justify his actions with reference to any notion of democracy.

For understanding how legalism has become a central factor in the Ivorian political arena, it is necessary to go back to the crisis of the Ivorian political system at the end of the ' 80 s and the distortion of the democratic game that characterized the Ivorian early experience with multi-party politics. As other African countries (Bratton \& Van de Walle 1997), Côte d'Ivoire was invested in the early 1990s by the wave of post-Cold War political liberalization. However, the introduction of multi-party politics and of some formal features of a democratic system has not led to the establishment of a full and sustainable democracy. Façade democratization has not been accompanied by the development of a culture of dialogue and by the acceptance of political competition (Akindès 2010) but has resulted in the fragmentation of the Ivorian political arena into mutually intolerant 'blocks'.

The three leaders who have dominated the Ivorian political game since the death of Houphouët-Boigny - Henri Konan Bédié, Laurent Gbagbo and Alassane Ouattara, plus the putschist general Robert Gueï, killed in 2002 - have been, to a different extent and in 
different manners, responsible for this downward spiral (Akindès 2010; Christian Bouquet 2007; Dozon 2000; Vidal 2003). Political dynamics have reinforced the association of each of the three leaders with a broad ethno-regional grouping: Bédié with the baoulé of central Côte d'Ivoire, Ouattara with the Ivorians of Northern and foreign origins (the so-called dioula) $)^{4}$ and Gbagbo with the autochthonous groups of Central-Western and South-Eastern Côte d'Ivoire, historically hostile to the regime of Félix Houphouët-Boigny. Since 1993, both the power-holders and the opposition have demonstrated their unwillingness to play the game of democracy in a fair manner: the first through the manipulation of the democratic rules (Bouquet 2007) and the second through the use of violence in rejecting the legitimacy of the incumbent (Vidal 2003).

While all this is well established, lesser remarked is the fact that the manipulation of democracy in Côte d'Ivoire has taken place to a large extent on the legal and constitutional terrain, through the manipulations of the key rules of eligibility and voting right (Bouquet 2011; Bovcon 2013). Differently from Houphouët-Boigny, Bédié, Gueï and Gbagbo were forced to give a cloth of democratic legitimacy to their rule and saw in the appeal to the law a possible way out. The resort to the manipulation of the law and especially of the Constitution - the supreme law - allowed those who controlled the state to claim allegiance to the formal rules of democracy, while they were violating its substance.

Bédié was the first to sponsor an amendment of the electoral code in order to prevent his rival Alassane Ouattara from running in the elections, introducing the obligation to be born 'from an Ivorian mother and father' for the presidential candidates. The usage of the law to distort the democratic game reached its peak in 2000 under the military transition guided by Gueï, when a new Constitution was submitted to referendum (Bouquet 2011). Its article 35 dealt with eligibility to the presidency, and would create a long-time debate in Ivorian politics. Often accused to be 'ivoiritaire' ('Ivoritarian'), the article was formulated in terms so vague and broad that it could be invoked to justify the 
exclusion of almost any candidate. ${ }^{5}$ As a matter of fact, it served to prevent twelve candidates out of seventeen from taking part to the 2000 elections, including those issued from two of the three Ivorian major political parties, the PDCI and the Rassemblement des Républicains (RDR) headed by Ouattara. ${ }^{6}$ Although Gbagbo eventually won, the exclusion of several major candidates and the turmoil that accompanied his election were going to weight heavily on his legitimacy as new Ivorian president.

While these debates over the eligibility to the presidency went on, another debate was opened by the FPI about the necessity of 'cleaning' the electoral lists from the alleged presence of foreigners and provided the rationale for the launch of a controversial process of identification of the population after Gbagbo's election (Banégas 2006; Marshall-Fratani 2006). In this context, the FPI relied on the argument of legal-bureaucratic rationalization to justify its stance. FPI militants claimed to be advocating the respect of the law in a domain - that of immigration - where since Houphouët-Boigny illegality and informalization had allegedly prevailed. They explicitly denied that immigration could be seen as a political, rather than legal-administrative, question (Campbell 2003: 37). Richard Banégas argues that FPI ideologues propounded a vision of a national revolution that involved building a new state modelled on the Weberian ideal (Banégas 2006). However the FPI's modernism also covered 'an exclusivist ideology of citizenship, founded on the principles of autochthony and adherence to a micro-territory' (Banégas 2006: 544). By redefining the access to citizenship and thus to the further benefits of legal power, the FPI could appropriate the legal command emanating from the state. In terms of electoral rules, what was at stake this time was the possible exclusion of electors suspected of being foreigners, rather than candidates, from the electoral consultations (Bouquet 2007). In the end, rather than encouraging the regeneration of the Ivorian state, the FPI's policies reinforced the cleavages that eventually led to the 2002 civil war and to nine years of $d e$ facto territorial division between the North and the South. 
The outbreak of the Forces Nouvelles (FN) insurgency marked the beginning of a new phase in the history of Ivorian post-Houphouët-Boigny turmoil. The rebellion began in the night of 19 September 2002 as a group of military officers of Northern ethnicity tried to overthrow the regime of Laurent Gbagbo. This group had already played a role in coup that had brought General Gueï to power, but had later broken with him. Most of its member lived in exile in Burkina Faso before participating in the insurgency. Although the coup was ultimately unsuccessful, it was well prepared, having benefited from complicities in Côte d'Ivoire's neighbouring countries, while the alleged connection of the putschists with the Ivorian opposition remains a matter of speculation. ${ }^{7}$ With the occupation by the putschists of the Centre-Northern half of the country, including Bouaké, the second biggest city of the country, and Korhogo, the main urban centre of the North, the coup effectively became a full scale insurgency. The rebels were eventually stopped in their offensive towards the South by the interposition of the French military. The conflict was frozen and the country cut in half.

Under the leadership of young former student leader Guillaume Soro, who would prove a skilled politician, the rebels organized politically. In their discourse, they claimed to be fighting against ivoirité and the Gbagbo regime's xenophobia (Gadou 2009; Fofana 2011). In their own defence, the members of the Gbagbo regime put forward an opposite interpretation of the crisis and of the rebellion. While the FN insisted that their rebellion should be seen as the outcome of long-term grievances, Gbagbo's supporters were rather pointing to the proximate causes of the insurgency. They painted the rebellion as a 'foreign terrorist attack', sponsored by Alassane Ouattara and by 'rogue states' of the sub-region such as Burkina Faso. ${ }^{8}$ The political and identity-based grievances of the FN were disqualified as pretexts for covering the insurgents' quest for power and wealth. However, the rebellion started soon to be portrayed also as illegal in its essence, as an attack against the 'juridically sovereign' state of Côte d'Ivoire. 
During the first months of the crisis, the nationalist virulence of the Ivorian regime seemed moderated by the acknowledgement that the international community, particularly France and the Economic Community of West African States' (ECOWAS), were to some extent responsive to its arguments and condemned the use of force by the part of the rebels (ECOWAS 2002). ${ }^{9}$ Gradually, however, ECOWAS' and France's decision to push for a negotiated solution to the crisis, which implied the at least partial recognition of the grievances of the rebels, prevailed. It was this new approach that informed the LinasMarcoussis peace talks, held in the outskirts of Paris in January 2003 and sponsored and mediated by France (Du Bois de Gaudusson 2003; Mehler 2009; Smith 2003).

As the Gbagbo regime felt increasingly abandoned and betrayed, particularly by the former colonial master, it increasingly deployed law and legalism against both internal enemies and the international community. Gbagbo's insistence on the law and the Constitution was already evident at the opening of the Linas-Marcoussis talks, in an interview that he gave to Le Monde reporter Stephen Smith. He argued that he would have 'trampled over the Constitution' had he accepted the nomination of a transitional government and insisted that the peace talks should not aim at organizing a transition but at restoring the 'legal order' (Le Monde 16.01.2003). After the end of the negotiations, the regime clung to legality and to the Constitution for justifying its refusal of the agreementnotably as far as it concerned the establishment of a transitional government and the powersharing arrangement with the rebels - and of the principle itself of a negotiated solution of the crisis. In this process, state sovereignty was identified with the Constitution and the legal framework of Côte d'Ivoire. The Constitution was sacralised, transformed into a symbol of independence of the country and opposed to international norms and decisions.

The ROLE OF LEGALISM IN IVORIAN POLITICS SINCE LINAS MARCOUSSIS TO THE POSTELECTION CRISIS 
In this paragraph I analyzes the employment and the evolution of legalist discourse by the Gbagbo regime during the Ivorian peace process, from Linas Marcoussis to the postelection crisis. I do it by looking at three key episodes: the debate over the legally binding force of the Linas-Marcoussis agreement, the discussion over the amendment of article 35 of the Ivorian Constitution and again, briefly, the post-election crisis.

\section{The debate over the legal biding force of the Linas-Marcoussis agreement}

An example of particularly significant juridical debate in this respect is the polemic over the legal binding force of the Linas-Marcoussis agreement. As Jean Du Bois de Gaudusson (2003) remarks, criticism by the Gbagbo regime in the aftermath of the conclusion of the agreement was not really focused over the content of the political programme defined by Linas-Marcoussis. Instead, it concentrated 'over the nature of the agreement, the constitutionality of its provisions, the modalities of its application and, in short, over its binding force over the parties' (Du Bois de Gaudusson 2003: 45). ${ }^{10}$

This controversy was opened on state television, the Radio Télévision Ivoirienne (RTI), by a senior politician who was going to play a key role in the 2010-2011 postelection crisis: Paul Yao N'dre, Minister of Interior of the outgoing Ivorian government and a well-known jurist. In his analysis of the Linas-Marcoussis agreement 'from a juridical and political angle', Yao N'dre stated that the Ivorian regime was not obliged to implement the agreement, as the latter was legally non valid (Notre Voie 30.01.2003). He justified this conclusion by several arguments. First, he argued, the negotiations had been conducted by actors who could not legally engage the will of the Ivorian state. Second, he stated that the agreement was legally subordinated to the Ivorian Constitution, but that at the same time it clashed with it on too many points, such as the provisions regulating the status of the transitional prime minister, the partial disarmament of the national armed 
forces, the imperative mandate given to the members of parliament. He concluded that Linas-Marcoussis was 'a null and void agreement'.

It is important to stress that the arguments of Yao N'dre were not just his own personal opinions, but were re-proposed by many other supporters of the regime. (Du Bois de Gaudusson 2003; Ba \& Wade 2005; Gomé 2004; Koulibaly 2003). In a more ambiguous form, they were adopted by Gbagbo himself in his public speech of 7 February 2003, the first after the conclusion of the Linas-Marcoussis agreement. Gbagbo claimed not to reject the 'spirit' of the Linas-Marcoussis agreement but expressed his determination to make the Constitution prevail. He endorsed most of Yao N'dre's views, including that the agreement had been 'a discussion between private entities' and that 'the most striking shortcomings [of Linas-Marcoussis]... are the parts of this text where it is in contradiction with the Constitution of Côte d'Ivoire'. He stated his intention 'to keep all the prerogatives that the Constitution grants me' and to apply the Constitution 'every time that there will be a contradiction between the text of Marcoussis and the Constitution' (Fraternité Matin 8.02.2003).

The legalist and legitimist disqualification of Linas-Marcoussis was politically useful to the Ivorian regime for at least three reasons. First, it was a formal argument. It did not imply that the grievances of the FN were not grounded, but pushed them in the background with respect to the illegal and illegitimate conduct of the rebels. The legal argument was thus presented as a condemnation of the use of force and violence for political ends. It thus allowed the Ivorian regime to escape from an open and frank debate over a series of problematic issues such as ivoirité or the land tenure regime that were deeply affecting Ivorian society. Secondly, considering the bias of the Ivorian Constitution in favour of the powers of the president, the regime could reject as anti-Constitutional any transitional solution that would have affected the powers and prerogatives of the president. Thirdly, the legalist argument was a way to reject the decisions taken at an international 
level by discussing their place in the legal order, rather than their substance. In this sense, legalist arguments were in part crafted for the international community. The fact that they were employed by top Ivorian state officials on the national media and that the exaltation of the Constitution featured prominently in the young patriots' discourses at popular 'agoràs' and 'parlements' (reference) suggest however that they were equally important in addressing the Ivorian internal public. ${ }^{11}$

\section{The polemics over the reform of the article 35 of the Ivorian Constitution}

Another key episode for understanding the importance of the juridical and formalist argument as a political instrument for the Gbagbo regime was the debate around the reform, required by the Linas-Marcoussis agreement, of article 35 of the Ivorian Constitution. Once more, the content of the article and of the reformulation proposed by the Linas-Marcoussis agreement ${ }^{12}$ were not the main focus. Rather, the FPI concentrated on the constitutional requirement that the Constitution could be amended only by referendum.

In order to find a solution to the issue of the article 35 , transitional prime minister Seydou Diarra and the international sponsors of the peace agreement decided they too would play the legal game and find a shortcut to reconcile the Constitution with LinasMarcoussis. The mechanism consisted in asking the president to use the exceptional emergency powers attributed to him by article 48 of the Constitution ${ }^{13}$ for promulgating the reforms, after their approval by the National Assembly, without the need to pass through a referendum. In July 2004 the so-called Accra III agreement, issued from new negotiations organized by UN Secretary General Kofi Annan and Ghanaian president John Kufuor, was supposed to incorporate this proposal. However, due to the opposition of the FPI, the final version concerning the use of extraordinary powers did not include the reform of the article 35. ${ }^{14}$ Pascal Affi N'guessan, former prime minister and president of the FPI, explained the FPI position in these words: 
... It is not for solving a little referendum issue that he [the president] is going to make use of the exceptional powers. An issue that, furthermore, does not fall within his authority. Because the revision of the eligibility condition is a matter of national sovereignty and our Constitution is clear on this point. The president of the Republic can employ his exceptional powers, but these powers do not give him the possibility to modify article 35 of the Ivorian Constitution. An abundant case law, as the jurists says, exists on the matter (Notre Voie 5.08.2004).

In November 2004, the launch by the Gbagbo regime of Opération Dignité - a campaign of air strikes on the rebel-controlled North - and the turmoil that followed, including clashes between the French army and the Ivorian young patriots, interrupted for some time the political dialogue. After the return to normalcy, the discussion over the reform of article 35 resumed under the mediation of Thabo Mbeki. Because of his reputation of anti-colonialist hero, the president of South Africa enjoyed the confidence and sympathy of the presidential side, which enabled him to obtain some important concessions. In December 2004, the FPI parliamentary group approved the amendment of the article, but continued to insist that a referendum was needed to finalize it. ${ }^{15}$

Why did the pro-Gbagbo camp insist so much over the need to amend the Constitution by referendum? Several reasons were behind the pro-Gbagbo request. First, given the difficulty to organize a referendum in a country cut in half, with a contested electoral list, the insistence over a referendum allowed for time and postponed the resolution of the crisis and the date of the presidential elections. Second, the FPI wanted to relaunch its long-time request to make the disarmament of the FN the precondition for constitutional reform, as it asked at least a partial demilitarization of the North for holding the referendum. However, as suggested by Affi N'guessan's argument that the reform of the Constitution was not within the authority of the president, the insistence over the 
amendment rules was also a way for Gbagbo to escape responsibility by appealing to 'the law'. This attitude may be seen, for instance, in Gbagbo's replies to an interview from the Senegalese newspaper Le Soleil at the end of November 2004. To the interviewer, who was asking him if at the time of his election he had 'intended to have the Constitution, notably its article 35, amended at a later stage', Gbagbo just replied: “"This is not my own problem. One shall look at the law"' (reprinted in Notre Voie 30.11.2004).

Within the presidential circle, the only discordant voice was the President of the Economic and Social Council Laurent Dona Fologo, a formerly senior figure of the PDCI who now supported Gbagbo. On several occasions, Fologo stated that the FPI should not reject a priori "“what I have called the positive rape of the Constitution [viol positif de la constitution]"' (Notre Voie 25.02.2005). However, the phrase 'positive rape' actually reinforced the impression that the Constitution was sacred and untouchable and any attempt to modify it amounted to a crime. At any rate, Fologo was rapidly disavowed by other more radical pro-Gbagbo leaders, such as FPI youth wing leader Konaté Navigué (Notre Voie 14.03.2005).

The post-electoral crisis of 2010-2011

The exaltation of the law and the discourse of legalism dominated the pro-Gbagbo rhetoric during the 2010-2011 post-electoral crisis. Formal and procedural arguments were invoked and the place of the Constitutional Council (CC) in the Ivorian legal framework was particularly stressed. Shortly after the ceremony of investiture, Gbagbo was particularly explicit in representing the crisis as a clash between the 'legalists' and 'those who have taken the road of illegality'.

I remind you that the Independent Electoral Commission (IEC) is an administrative authority, while the $\mathrm{CC}$ is the highest jurisdiction of Côte d'Ivoire. The two institutions are not comparable and it is 
illegitimate to compare them. Their decisions are of a different nature. They have neither the same foundation, nor the same impact... I have waited for the law to be said... They want to scare us, but they cannot expect that the legalists will surrender to those who have taken the road of illegality. Those who respect the Constitution and would give their life to defend it will not surrender to those who want to demolish the foundations of the Republic and of democracy (Gbagbo 2010).

During the post-electoral crisis, the sovereignty of the country and the will of the 'people' were increasingly identified by Gbagbo with the principle of legality. He claimed during his oath of office that the sovereignty of Côte d'Ivoire was 'what I am in charge of defending' and that 'the presidential seat has an owner, it is the people. It is to the people and to the people only that one shall speak'. ${ }^{16}$ Gbagbo's point was that the laws and institutions of the country were the true expression of the 'will of the people' when in reality they had been, to a good extent, engineered from above: the CC judges had been appointed by the president, not elected. His populist discourse masked the fact that the CC was in fact denying many citizens the right to express themselves by invalidating their vote.

The superiority of the CC was also employed by Gbagbo's supporters to neutralize the certification of the votes by UN SRSG Choi and denounce it as illegitimate. Fraternité Matin, for instance, published an analysis by well-known jurist Ouaraga Obou who, while not a pro-Gbagbo hardliner, expressed arguments that were very popular among Gbagbo's supporters. He notably introduced a subtle distinction between 'certification' and 'validation' and argued that the UN certification mandate did not change the fact that 'the latter authority is a prerogative of the CC only' (Fraternité Matin 6.12.2010).

The legal defence of Gbagbo's stance in the post-election crisis was however particularly weak. Notably, by invalidating the elections in a specific area of the country 
and then proceeding to revert the results, the $\mathrm{CC}$ itself had violated the electoral code (Republic of Côte d'Ivoire 2008) and thus the law it claimed to defend. ${ }^{17}$ Moreover, the CC's statement was even poorly written from a legal point of view, as it called 'departments' what were in fact election coordination centre. ${ }^{18}$ The weakness of the legal arguments was not perhaps a secondary factor behind the almost unanimous opposition that Gbagbo met at the international level and behind his final fall. For the rest, the 20102011 the attitude of Gbagbo regime during the post-electoral crisis was in full continuity with its past strategy (ICG 2011: 6). By the same tactic that had allowed him in the past to challenge peace agreement and international decisions, Gbagbo tried now engineer a 'legal' victory after losing at the ballot boxes.

\section{CONCLUSION}

During the Ivorian crisis, legal arguments were central in the political discourse of Laurent Gbagbo and his allies and constituted an important component of the nationalism of the Gbagbo regime and of its conception of the defence of the Constitution and of the national sovereignty.

The significance of this aspect of Ivorian nationalism has been underestimated or passed unnoticed, perhaps because obscured by the anticolonialist rhetoric of the regime and because the ideologically conservative tone of the formalist and procedural appeal to the law contrasted with the image of a 'revolutionary' Laurent Gbagbo. The legal argument was nevertheless central in the struggle of the Gbagbo regime to stay in power. The regime established an equation between the law, national sovereignty and democracy. Sovereignty was identified with the Constitution and the internal legal framework of Côte d'Ivoire, which were sacralised as the true representation of the will of the 'people.' Respect for the Constitution and the law more generally was used to justify the refusal to implement 
internationally-sponsored peace agreements and to comply with international norms and decision.

The importance of the law in the Ivorian political struggle provides evidence in favour of Englebert's argument that the juridical sovereignty conferred at the international level translates internally in the centrality of the legal command emanating from the state. This power becomes a key instrument of domination in politics and in the society and also contributes to explain the resilience of the state in times of crisis - because legal command belongs to the state only. Informal relations of clientelism and patronage matters in Africa, but what provides access to rents are the formal institutions of the state, endowed by legal command. Legalist nationalism shall also be seen in the context of an 'invented' postcolonial state, lacking cultural bonds or a history of national liberation able to provide a 'foundation myth' for a nationalist narrative.

The problem of (flawed) transition to democracy shall be also taken into account. In the last two decades, African states have come under increasing pressure to democratize. This has further strained the legitimacy claims of their rulers, in a context where neopatrimonialism still constitutes the predominant form of governance in many of these states. Some African rulers have responded by manipulating the law in a way to convey the impression that the formal rules of democracy are followed, while the substance is violated (Van de Walle 2002). For an example, Daniel Posner and Daniel Young singled out nine African countries (Malawi, Nigeria, Zambia, Chad, Gabon, Guinea, Namibia, Togo, Uganda) for the period 1990-2005 where the president attempted to amend the Constitution in order to serve a third term, although only in six of them was the attempt successful (Posner \& Young 2007).

An optimistic interpretation suggests that the degenerations of legalism may be part of a twofold process of statebuilding and democratization, where informal practices are gradually replaced by institutionalized rules. The institutionalization of political power 
may become a positive force, as the examples of those African countries where Constitutional Courts have managed to emancipate themselves from the executive power and to take over a role of defenders of democracy suggest (Bovcon 2013). This view is expressed by Posner and Young for whom the fact that African leaders who have managed to circumvent restrictions 'have done so through formal institutional channels rather than extraconstitutional means' (Posner \& Young 2007: 127) is in itself a positive development.

This view echoes that of the international practitioners of 'good governance' who have generally tended to highlight the positive and emancipatory potential of the law, as guarantee of democracy and of individual rights. This trend can be explained on the one hand by the role that the Constitutions and the rule of law have had in the struggle for democracy in European and Western history. On the other hand, it stems from the 'highly modernist' (Scott 1999) spirit that pervades international institutions and development agencies, their ambition to create functional states at the image of the Western ones and to 'order' the world making it readable.

The Ivorian case suggests that the issue is more complex. Law and disorder may in fact not be opposite but constitutive of each other (Comaroff \& Comaroff 2007) and there may be no contradiction between a political agenda that purportedly supports the principle of legality and detrimental partisan policies. The law and even the Constitution, instead of setting limits to the power-holders, can easily become instruments in the internal and international political struggle. It is possible that, to some extent, the Ivorian obsession with the law is part of a political culture where the principle of justice, although frequently invoked in a partisan manner, is valued and sets limits to political violence and arbitrariness (McGovern 2010). It is also possible that the gradual institutionalization of rules, even when these rules are illiberal, may lay a favourable breeding ground to a future democratic transformation, as in the case of post-apartheid South Africa (Meierhenrich 2008). However, the Ivorian case also suggests that the institutionalization of political 
power can encourage political leaders to pursue policies more dangerous than the ones that they would have pursued if they were unconstrained. For instance, the need to find legally plausible arguments in order to exclude Ouattara from running in the presidency led in Côte d'Ivoire to the opening of the debate on the identity of the 'foreigners', which polarized the Ivorian society with detrimental consequences. The Ivorian case also suggests that the idea of bureaucratic rationalisation that underline many externally sponsored statebuilding efforts may dangerously converge with the instrumental use of law and formal institutions by local political actors. In the end, such effort to redefine the state may lead to state decay, rather than statebuilding.

What role the law will play in the future of Côte d'Ivoire remains to be seen. There are signs however that the current Alassane Ouattara administration is not decidedly breaking with the past (Bovcon 2013) and that the involvement of the International Criminal Court in Côte d'Ivoire is changing little in a context where the law continues to be seen as a tool in the hands of the powerholders, rather than a weapon of the weak.

\section{NOTES}

1. For an analysis of the electoral results and of the subsequent dispute, see Bassett 2011 and European Union 2011.

2. For recent discussions of neo-patrimonialism, see Erdmann and Engel (2007) and Bach and Gazibo (2012).

3. See the UN official website: <http://www.un.org/en/ruleoflaw/index.shtml>, accessed 16.01.2013.

4. This is the etiquette give in Côte d'Ivoire to Northern Ivorians and Ivorians of foreign descent. For a discussion of the construction of the category of dioula see Cutolo 2010.

5. The text of the article 35 is the following: 'The candidate to the presidential election shall not be younger than forty years nor older than sixty-five years. He shall be Ivorian by birth, born by a father and mother themselves Ivorians by birth. He shall never have renounced the Ivorian nationality. He shall never 
have claimed another nationality. He shall have had his residence in Côte d'Ivoire for five years without interruptions at the moment of the presidential elections and have totalized ten years of effective presence in the country... The candidate to the Presidency of the Republic shall be in a full state of mental and physical well-being, which must be duly certified by a board of three medical doctors, nominated by the Constitutional Council out of a list compiled by the Professional Association of the Medical Doctors. These three physicians must take an oath by the Constitutional Council. The candidate must be of a good character and of a great integrity. He shall disclose his patrimony and justify its origins' (République de Côte d'Ivoire 2000: art. 35).

6. Gbagbo's FPI was the only of the three top Ivorian parties that could secure the participation of its candidate. Notably, three candidates tried to run under the banner of the PDCI and all were declared ineligible. Bédié was one of the three but due to his unpopularity the PDCI had presented another official candidate, former Minister of Interior Emile Constant Bombet (Bouquet 2011).

7. Although there was a substantial coincidence between the agenda of the insurgents and that of the RDR with Ouattara repeatedly pointed out by the Gbagbo regime as the 'father of the rebellion', allegations of complicity have never been proven and the origins of the FN still remain to some degree unclear. For a discussion, see International Crisis Group 2003.

8. See for instance 'Les ambassadeurs expriment le soutien de leur gouvernements à la Côte d'Ivoire', Notre Voie, 25.09.2002 and 'Pr. Mamadou Koulibaly: «Le Parlement exhorte le gouvernement à saisir le Conseil de Sécurité des Nations Unies»', Notre Voie, 26.09.2002.

9. About France, see French Foreign Affairs Ministry, press conference 'Côte d'Ivoire', 2 October 2002 $<$ http://basedoc.diplomatie.gouv.fr/exl-php/cadcgp.php $>$ accessed 15.04.2010 and French Foreign Affairs Ministry, press conference 'Côte d'Ivoire', 14 October 2002, <http://basedoc.diplomatie.gouv.fr/exlphp/cadcgp.php> accessed 15.04.2010.

10. Italic in the original text.

${ }^{11}$ In fact, Ivorian dean Constitutionalist Ouraga Obou, who served as an advisor for Prime Minister of the government of national unity Seydou Diarra in 2003 and was regularly in touch with French mediator Pierre Mazeaud during the Linas Marcoussis negotiations notices that the so-called international community generally failed to understand the importance of the law and the Constitution during the crisis (Ouaraga Obou, personal communication). This facilitated Gbagbo's and his supporters' efforts to claim in front of the Ivorian public that the international agreements were unconstitutional and illegitimate 
12. The proposed new provision stated the following: 'the candidate shall benefit of his civil and political rights and be aged at least thirty-five. He must not hold any other nationality but the Ivorian one and must be born of a father or a mother who is Ivorian by birth'.

13. 'When the institutions of the Republic, the independence of the Nation, the integrity of its territory or the execution of its international engagements are threatened in a serious and immediate manner and the regular functioning of the public and constitutional powers is interrupted, the President of the Republic takes the exceptional measures that the situation requires after a compulsory consultation with the President of the National assembly and the President of the Constitutional council. He informs the nation with a message' (République de Côte d'Ivoire 2000: art. 48).

14. 'In view of the persistent grave threat to the territorial integrity of Côte d'Ivoire caused by the continuing crisis, the President of the Republic shall use the powers conferred upon him by the Constitution to implement by the end of September 2004 the provisions of section III on eligibility of the Programme of the Government of National Reconciliation annexed to the Linas-Marcoussis Agreement' (Accra III: 6).

15. For the full declaration see 'Déclaration du groupe parlementaire FPI', Notre Voie 11.12.2004.

16. 'Laurent Gbagbo, après son investiture', cit.

17. For an in depth discussion, see European Union 2011, which also includes as an appendix the full text of the Decision of the CC and a legal analysis of it; ICG 2011; Bassett 2011.

18. The confusion derived from the fact that the electoral administration mirrors the territorial administration as it stood before the creation of new departments in 2008. 


\section{REFERENCES}

Akindès, F. 2004. The Roots of the Military-Political Crises in Côte d'Ivoire. Uppsala: Nordiska Afrikainstitutet.

Akindès, F. 2010. 'Côte d'Ivoire since 1993: the risky reinvention of a nation', in L. Whitfield \& A. R. Mustapha, eds. Turning Points in African Democracy. Suffolk: Boydell \& Brewer, $31-49$.

Alexander, A.S. 1963, 'The Ivory Coast Constitution: An Accelerator, not a Brake', The Journal of Modern African Studies, 1, 3: 293-311.

Arnaut, K. 2008. 'Mouvement patriotique et construction de 'l'autochtone' en Côte d'Ivoire', Afrique et développement, 23, 3: 1-20.

Ba, C. K., \& Wade, M. 2005. Laurent Gbagbo: c'est le plus difficile qui est le chemin. Abidjan: La Réfondation.

Bach, D. and M. Gazibo (eds) 2012, Neopatrimonialism in Africa and Beyond. London: Routledge.

Banégas, R. 2006. 'Côte d'Ivoire: Patriotism, Ethnonationalism and other African modes of Self-writing', African Affairs, 105, 421: 535-552.

Bassett, T. J. 2011. 'Winning coalition, sore loser: Cote d'Ivoire's 2010 presidential elections', African Affairs, 110, 440: 469-479.

Bayart, J.-F. 1989. L'Etat en Afrique: la politique du ventre. Paris: Fayard.

Bouquet, C. 2011. Côte d'Ivoire: Le désespoir de Kourouma. Paris: Armand Colin.

Bouquet, C. 2007. 'Le mauvais usage de la démocratie en Côte d'Ivoire', L'Espace Politique, 3, 3. <http://espacepolitique.revues.org/index894.htm>, accessed 11.12.2012.

Bratton, M., \& Van de Walle, N. 1997. Democratic experiments in Africa: regime transitions in comparative perspective. Cambridge: Cambridge University Press.

Bøås, M. 2009. “"New” Nationalism and Autochthony. Tales of Origin as Political Cleavage', Africa Spectrum, 44, 1: 19-38. 
Bovcon, M. 2013, 'The progress in establishing the rule of law in Côte d'Ivoire under Ouattara's presidency', unpublished paper, $\quad<$ http://www.waanalyst.com/docs/Courts_in_CI.pdf>, accessed 31.08.2013.

Campbell, B. 2003. 'Defining New Development Options and New Social Compromises in the Context of Reduced Political Space: Reflections on the Crisis in Cote d'Ivoire', African Sociological Review, 7, 2: 29-44.

Chabal, P., \& Daloz, J.-P. 1999. Africa works: disorder as political instrument. Oxford: James Currey.

Clapham, C. 1998. 'Degrees of Statehood', Review of International Studies, 24, 2: 143-157.

Collier, P. 2000. 'Doing well out of war: an economic perspective', in M.R. Berdal and D. Malone, Greed and Grievance: Economic Agendas in Civil Wars. London: Lynne Rienner.

Comaroff, J., \& Comaroff, J. 2007. 'Law and disorder in the postcolony', Social Anthropology, 15,2: 133-152.

Cutolo, A. 2010. 'Modernity, Autochtony and the Ivorian Nation: the end of a Century in Côte d'Ivoire', 80, 94, 527-552.

Cutolo, A., \& Banégas, R. 2012. 'Gouverner par la parole: parlements de la rue, pratiques oratoires et subjectivation politique en Côte d'Ivoire', Politique Africaine, 127: 21-48.

Dorman S., D.P. Hammet, P. Nugent (eds) 2007. Making nations, creating strangers: states and citizenship in Africa. Leiden: Brill.

Dozon, J. 2000. 'La Côte d'Ivoire entre démocratie, nationalisme et ethnonationalisme', Politique Africaine, 78: 45-62.

Du Bois de Gaudusson, J. 2003. 'L'accord de Marcoussis, entre droit et politique', Afrique contemporaine, 206: 41-55.

Economic Community of the West African States (ECOWAS) 2002. Accord d'Accra I sur la Côte d'Ivoire. Abidjan: Republic of Côte d'Ivoire, Programme Nationale de Réinsertion et $\begin{array}{lll}\text { Réhabilitation } & \text { Communautaire } \quad \text { (PNRRC) } & <\text { http://www.pnrrc- }\end{array}$ ci.org/index.php?option $=$ com_content\&view $=$ article\&id $=76 \&$ Itemid $=40>$, accessed 6.10.2011. 
Erdmann, G. \& U. Engel 2007, 'Neopatrimonialism reconsidered: critical review and elaboration of an elusive concept', Commonwealth \& Comparative Politics, 45, 1: 95-119.

Englebert, P. 2000. Pre-Colonial Institutions, Post-Colonial States, and Economic Development in Tropical Africa, Political Research Quarterly, 53,7, 7-36.

Englebert, P. 2009. Africa: unity, sovereignty, and sorrow. Boulder, Colo.: Lynne Rienner Publishers.

European Union 2011, Côte d'Ivoire. Rapport Final, Election Présidentielle 31 octobre - 28 novembre 2010, Brussels : Mission d'Observation Electorale de l'Union Européenne.

Fofana, M. 2011. 'Des Forces nouvelles aux Forces républicaines de Côte d'Ivoire. Comment une rébellion devient républicaine', Politique Africaine, 122: 161-178.

Gadou, D. 2009. 'Crise ivoirienne: enjeux et sens d'une mobilisation patriotique', Afrika focus, 22, 2: $65-84$.

Gbagbo, L 2010. 'Message à la Nation du président Laurent Gbagbo relatif à la Situation Post$\begin{array}{llll}\text { Electorale', } & 21 & \text { December } & 2010\end{array}$ $<\mathrm{http} / / /$ www.cotedivoirepr.ci/?action=show_page\&id_page=6819>, accessed 27.12.2010.

Gomé Gnohité H. 2004. Le Rempart: Attaque Terroriste contre la Côte d'Ivoire. Paris: L'Harmattan.

Hellweg, J. 2012. 'In Search of Lost Legality: Justice, Constitutionality, and the Rome Statute in Côte d'Ivoire', Cultural Anthropology Online, March 192012. $<$ http://www.culanth.org/fieldsights/206-in-search-of-lost-legality-justice-constitutionalityand-the-rome-statute-in-cote-d-ivoire>, accessed 30.08.2013.

Herbst, J. I. 2000. States and power in Africa: comparative lessons in authority and control. Princeton, N.J.: Princeton University Press.

Hyden, G. 2005. African Politics in Comparative Perspective. Cambridge: Cambridge University Press.

International Crisis Group (ICG) 2011. Côte d'Ivoire: is war the only option? Africa Report $\mathrm{n}$. 171. 
Jackson, R. H. 1990. Quasi-states: sovereignty, international relations, and the Third World. Cambridge: Cambridge University Press.

Jackson, R. H., \& Rosberg, C. G. 1982a. Personal Rule in Black Africa: Prince, Autocrat, Prophet, Tyrant. Berkeley: University of California Press.

Jackson, R. H., \& Rosberg, C. G. 1982b. 'Why Africa's Weak States Persist: The Empirical and the Juridical in Statehood', World Politics, 35, 1: 1-24.

Joseph, R. 2003. 'Nation-State Trajectories in Africa', Georgetown Journal of International Affairs, 4: 13-20.

Koné, G. 2011. Sociogènes et Dynamique du Mouvement 'Jeune Patriote' en Côte d'Ivoire. Université de Bouaké, Côte d'Ivoire: PhD Thesis.

Koulibaly, M. 2003. La Guerre de la France contre la Côte d'Ivoire. Paris: L’Harmattan.

Krasner, S. D. 1999. Sovereignty: organized hypocrisy. Princeton, N.J.: Princeton University Press.

Maddox Toungara, J. 1990, 'The Apotheosis of Cote d'Ivoire's Nana Houphouët-Boigny ', Journal of Modern African Studies, 28, 1: 23-54.

Meierhenrich J. 2010. The Legacies of Law: Long-Run Consequences of Legal Development in South Africa, 1652-2000, Cambridge: Cambridge University Press, 2010

Marshall-Fratani, R. 2006. "The War of "Who Is Who": Autochthony, Nationalism, and Citizenship in the Ivorian Crisis', African Studies Review, 49, 2: 9-43.

McGovern 2010. 'Proleptic Justice: the Threat of Investigation as a Deterrent to Human Rights Abuses in Cote d'Ivoire', in K.M. Clarke and M. Goodale, Mirrors of Justice: Law and Power in the Post-Cold War Era, Cambridge: Cambridge University Press.

McGovern, M. 2011. Making War in Cote d'Ivoire. Chicago: University of Chicago Press.

Mehler, A. 2009. 'Peace and Power Sharing in Africa: A Not So Obvious Relationship', African Affairs, 108, 432: 453-473.

Piccolino 2012. 'David against Goliath in Côte d'Ivoire? Laurent Gbagbo's war against Global Governance', African Affairs, 111, 442: 1-23. 
Posner, D. N., \& Young, D. J. 2007. 'The Institutionalization of Political Power in Africa', Journal of Democracy, 18, 3: 126-140.

Republic of Côte d'Ivoire 2000. Loi n. 2000-513 du ler août 2000 portant Constitution de la République de Côte d'Ivoire, adoptée par référendum le 23 juillet 2000. Abidjan: République de Côte d'Ivoire.

Republic of Côte d'Ivoire 2003. Linas Marcoussis Agreement. Official English version published as Annex I to the letter dated 27 January 2003 from the Permanent Representative of France to the United Nations addressed to the President of the Security Council. New York: United Nations.

Republic of Côte d'Ivoire 2004. High Level meeting on Côte d'Ivoire, Accra 29-30 July 2004: Accra III Agreement on Côte d'Ivoire. Official English version published as Annex to the letter dated 2 August 2004 from the Permanent Representative of Ghana to the United Nations addressed to the President of the Security Council. New York: United Nations.

Republic of Côte d'Ivoire 2008. Code électoral de Côte d'Ivoire, consolidated version, Abidjan : Independent Electoral Commission.

Scott, J. C. 1999. Seeing Like a State: How Certain Schemes to Improve the Human Condition Have Failed. New Haven: Yale University Press.

Smith, S. 2003. 'La Politique d'Engagement de la France à l'Epreuve de la Côte d'Ivoire'. Politique Africaine, 89: 112-126.

Van de Walle, N. 2002. 'Elections without democracy: Africa's Range of Regimes', Journal of Democracy, 13, 2: 66-80.

Vidal, C. 2003. 'La brutalisation du champ politique ivoirien, 1990-2003', Revue Africaine de Sociologie, 7, 2: 45-57.

Young C. 1986. 'Nationalism, Ethnicity, and Class in Africa: A Retrospective', Cahiers d'études africaines, 26, $103:$ 421-495.

\section{Newspapers}

Fraternité Matin, Abidjan. Notre Voie, Abidjan. Le Monde, Paris 